\title{
DEVELOPMENT AND VALIDATION OF AN ANALYTICAL METHODOLOGY FOR QUANTIFICATION OF Al IN ALUMINA-BASED MATERIALS BY ${ }^{27} \mathrm{Al}$ SOLID-STATE NMR
}

\section{Luizianne P. Alves',2, Rosane A. S. San Gil1,2, ${ }^{1}$, Arnaldo C. Faro Júnior ${ }^{2}$, Leandro B. Borré2, Stevie H. Lima' ${ }^{1}$, Helio R.X. Pimentel ${ }^{1}$ and Angela S. Rocha ${ }^{3}$}

1Universidade Federal do Rio de Janeiro, Instituto de Química, 21941-909 Cidade Universitária - RJ, Brazil. 2Universidade Federal do Rio de Janeiro, Instituto de Pesquisa em Produtos Naturais, CCS, Cidade Universitária - RJ, Brazil; ${ }^{3}$ Universidade do Estado do Rio de Janeiro, Instituto de Química, Rio de Janeiro - RJ, Brazil

\section{ARTICLE INFO}

Article History:

Received $14^{\text {th }}$ December, 2020

Received in revised form

$25^{\text {th }}$ January, 2021

Accepted $10^{\text {th }}$ February, 2021

Published online $17^{\text {th }}$ March, 2021

\section{Key Words:}

SSNMR, qNMR, Validation,

${ }^{27} \mathrm{Al}$ spin Counting, Diamagnetic Materials.

\begin{abstract}
In this work, a simple protocol for counting the $\mathrm{Al}$ spins present in diamagnetic materials used as carriers and catalysts based on ${ }^{27} \mathrm{Al}$ solid-state nuclear magnetic resonance using routine $4 \mathrm{~mm}$ rotors was developed and validated. The acquisition parameters were optimized, and validation tests were performed using a standard sample of $\gamma$-alumina with a known aluminium concentration. The validation results indicated that solid-state NMR can be used for the quantification of quadrupolar aluminium (mmol Al. $\mathrm{g}^{-1}$ material) in diamagnetic materials by employing non-special tools with satisfactory results, similar to the NMR quantitative analysis of dipolar nuclei in solids.
\end{abstract}

*Corresponding author: Rosane A. S. San Gil

Copyright (C) 2021, Luizianne P. Alves et al. This is an open access article distributed under the Creative Commons Attribution License, which permits unrestricted use, distribution, and reproduction in any medium, provided the original work is properly cited.

Citation: Luizianne P. Alves, Rosane A. S. San Gil, Arnaldo C. Faro Júnior, Leandro B. Borré, Stevie H. Lima, Helio R.X. Pimentel and Angela S. Rocha. "Development and Validation of an Analytical Methodology for Quantification of Al in Alumina-based Materials by 27Al Solid-State NMR", International Journal of Development Research, 11, (03), 45249-45255.

\section{INTRODUCTION}

Nuclear magnetic resonance (NMR) spectroscopy is one of the most important tools of structural characterization and has also been used for quantitative purposes. The advantage of NMR over other analytical techniques is that it is a primary standardization method, similar to gravimetry, titration techniques and coulometry, among others. For this reason, the construction of an analytical curve and the use of reference standards identical to the analytes are in principle unnecessary (Malz et al., 2005). The use of NMR for quantification allows the substances under investigation to be identified and quantified directly from the spectrum obtained since the NMR signal area is directly proportional to the number of nuclei that contribute to the observed signal (Liu et al., 1996; Mingyue et al., 2021; Wawer et al., 2008). Although NMR is a primary quantification technique, its use for the evaluation of samples in solid form (MAS NMR) is mainly focused on nuclei with $\operatorname{spin}=1 / 2$.
For ${ }^{13} \mathrm{C}$ quantification, usually a combination of cross-polarization (CP MAS, in which the signal detection is modulated by the $\mathrm{H}$ population near the site) and direct polarization (DP MAS) spectra is used to obtain quantitative data (Bakhmutov et al., 2006; Smerniket al., 2000; Wang et al., 2018; Wawer, 2008). ${ }^{27} \mathrm{Al}$ is a nucleus with spin $\mathrm{I}=5 / 2$ (therefore quadrupolar), with a natural abundance of $100 \%$ and a quadrupole moment of $0.1466 \times 10^{-28} \mathrm{~m}^{2}$. In the presence of an external magnetic field $B_{o},{ }^{27} \mathrm{Al}$ nuclei possess six Zeeman states defined by the $\mathrm{m}=5 / 2,3 / 2,1 / 2,-1 / 2,-3 / 2$ and $-5 / 2$ orientational quantum numbers (Benndorf et al., 2017) and five transitions $(\mathrm{n} \rightarrow$ $\mathrm{n}+1 ; \mathrm{n}=-I$ to $I-1$ ). Although for quantitative NMR analysis of spin $\mathrm{I}=1 / 2$ nuclei, the use of $\pi / 2$ single pulse excitation is indicated, in quadrupolar nuclei the quadrupolar interactions are orientation dependent, and the extent to which they are excited affects the intensities observed (Haouas et al., 2016). In this situation, the line intensity could be measured for quantification purposes following the protocol based on a reduced pulse angle such that $(I+1 / 2) w_{1} T_{p} / 6$ to obtain a less than 5\% error, as noted by Smith and van Eck (1999), by using single pulse excitation, and the resulting signal (FID - 'free 
induction decay') is recorded as the spins return to equilibrium. The spin system relaxes back to equilibrium state by first-order processes characterized by two relaxation times, T1 and T2 (Wawer, 2008). T1 is the longitudinal relaxation time, that measures how rapidly the spins return to the equilibrium and is experimentally determined for each signal. Additionally, the recycle delay (D1) must be adjusted to a value of at least $5 \times \mathrm{T} 1$. In addition, the position of the centre of gravity is dependent on the electric field produced by the environment, so the quantitative detection of ${ }^{27} \mathrm{Al}$ in solid samples is hampered by the possibility of a loss of signal area due to, among other factors, the presence of sites with distorted symmetry (Gee et al., 2001). Fortunately, for diamagnetic samples, the effect can be neglected, as is the case for the samples investigated in this work.

Aluminium oxide, $\mathrm{Al}_{2} \mathrm{O}_{3}$, generally known as alumina, is a very important industrial material with several applications. These applications range from electronics, optics and mechanical engineering to biomedicine (Ananthanarayanan et al., 2010; Saini et al., 2017). Many polymorphs of alumina are known as transition aluminas and are traditionally obtained from the calcination of their precursors, usually hydroxides or oxy-hydroxides (Chagas et al., 2014; Liu et al., 2015). In petrochemical industries, $\gamma-\mathrm{Al}_{2} \mathrm{O}_{3}$ is used as a catalyst or catalyst support (Rocha et al., 2007; Li et al., 2009; Liu et al., 2010; Arias et al., 2013).

The characterization of heterogeneous catalysts is fundamental to explain and predict some of their main properties. Quantitative NMR data of quadrupolar nuclei such as ${ }^{27} \mathrm{Al}$ are relevant information that can help in understanding the catalytic phenomenon (Fyfe et al., 2001; Lima et al., 2014; Man et al., 1988). A significant portion of the starting materials for the preparation of catalysts have $\mathrm{Al}$ in their composition, such as alumina (Firdous et al., 2019; Paglia et al., 2003), metal-supported aluminas (Al-Fatesh et al., 2018; Claude et al., 2020; Weissman et al., 1996), bauxite and Al-containing mixed oxides. Bauxite is a natural mineral and is the main source of aluminium. It is a heterogeneous mixture of trihydroxides (gibbsite) and oxyhydroxides (diaspore and boehmite), predominantly gibbsite, aluminium silicates, iron and/or titanium dioxide (Constantino et al., 2002; Crosson et al., 2006). Many problems related to NMR quantification through spin counting can be avoided by considering the sample as part of the circuit involved in signal generation and detection.

The amplitude variation due to the dielectric constant and conductivity is temperature dependent and can be inferred based on the evolution of the quality factor of the probe. By controlling the probe head temperature, this factor can be considered constant (Haouas et al., 2018). For the rotor sample holder, Ziarelli et al. (2007), Sanchez et al. (2008), and recently Brinkmann et al. (2019) developed procedures to perform quantitative measurements of ${ }^{13} \mathrm{C}$ and ${ }^{19} \mathrm{~F}$ by solid-state NMR such that the entire sample contributed to signal formation. They measured the contribution to the signal from different areas of a $4 \mathrm{~mm}$ rotor, and it was evidenced that a higher sensitivity is present in the central part that homogeneously responds to the excitation. The lower signal contributions from the top and bottom of the rotor were attributed to the effects of the inhomogeneity of the radiofrequency field, and the exclusion of those volumes contributes to reliable quantitative analysis. Thus, the authors used a specially designed rotor that excluded the top and bottom rotor areas. Regardless of the satisfactory results, this protocol is not practicable in routine solid-state NMR labs due to the unconventional rotors and inserts.

Considering the potential of the solid-state NMR technique as an analytical tool, the importance of following validated protocols during quantitative work and the use of alumina worldwide, the objective of this work was to present the development and validation of a methodology for $\mathrm{Al}$ quantification by this method, following the protocols recommended by distinct resolutions (ABNT, 2016; ANVISA, 2003; EURACHEM/CITAC, 2012; EUROLAB, 1/2014; INMETRO, 2001). Although there are some examples of spin counting of quadrupolar nuclei by solid-state NMR (Haouas et al.,
2016; Fitzgerald et al., 1994; Jiao et al., 2005), to the best of our knowledge, this is the first time a validated protocol for $\mathrm{Al}$ quantification has been reported using a routine $4 \mathrm{~mm}$ device. Success was achieved in the quantification of $\mathrm{Al}$ present in samples of alumina-based supports and catalysts in which diamagnetic nuclei are dominant.

\section{Experimental}

Preparation of samples: A sample of Pural Alumina (from Sasol Inc., USA) with known alumina content was used as a reference for the validation tests. The developed protocol was applied for the quantification of $\mathrm{Al}$ in the following materials: an alumina synthesized in the laboratory, a sample of certified bauxite (no. NCS DC 61105 provided by China National Analysis Center, China) and supports containing $\mathrm{Nb}_{2} \mathrm{O}_{5}$ in $\mathrm{Al}_{2} \mathrm{O}_{3}$ with $11 \% \quad \mathrm{Nb}_{2} \mathrm{O}_{5}$ and $20 \%$ $\mathrm{Nb}_{2} \mathrm{O}_{5}$, provided by the Heterogeneous Catalysis Laboratory of the Institute of Chemistry (IQ) of the Universidade Federal do Rio de Janeiro (UFRJ, Brazil). Table 1 shows the details of the materials used, while the chemical composition is indicated in Table S1 (Supplementary Material). Sodium chloride Sigma Aldrich (PA) was used as the diluent in the preparation of solid solutions with an $\mathrm{Al}$ percentage in the range of 5 to $100 \%$.

All samples were pulverized and weighed on a Shimadzu brand AY220 semi-analytical balance $(220 \mathrm{~g}$ capacity and $0.01 \mathrm{mg} / 0.1 \mathrm{mg}$ accuracy).

Table 1. Diamagnetic materials studied in this work

\begin{tabular}{lll}
\hline Material & Formula & Origin \\
\hline$\gamma$-alumina Pural & $\mathrm{Al}_{2} \mathrm{O}_{3}$ & Sasol Inc. USA \\
\hline$\gamma$-aluminaS & $\mathrm{Al}_{2} \mathrm{O}_{3}$ & Synthesis product \\
\hline Bauxite & $\mathrm{AlO}_{2}(\mathrm{OH})$ & China National Anal.Center \\
\hline $11 \mathrm{Nb}_{2} \mathrm{O}_{5} / \mathrm{Al}_{2} \mathrm{O}_{3}$ & $\mathrm{Nb}_{2} \mathrm{O}_{5} / \mathrm{Al}_{2} \mathrm{O}_{3}$ & Lima et al. (2014) \\
\hline $20 \mathrm{Nb}_{2} \mathrm{O}_{5} / \mathrm{Al}_{2} \mathrm{O}_{3}$ & $\mathrm{Nb}_{2} \mathrm{O}_{5} / \mathrm{Al}_{2} \mathrm{O}_{3}$ & Lima et al. (2014) \\
\hline $\mathrm{MoAl}$ & $\mathrm{Mo} / \mathrm{Al}_{2} \mathrm{O}_{3}$ & Rocha et al. (2007) \\
\hline $\mathrm{MoAlNb}$ & $\mathrm{Mo} / \mathrm{Nb}_{2} \mathrm{O}_{5} / \mathrm{Al}_{2} \mathrm{O}_{3}$ & Rocha et al. (2007) \\
\hline
\end{tabular}

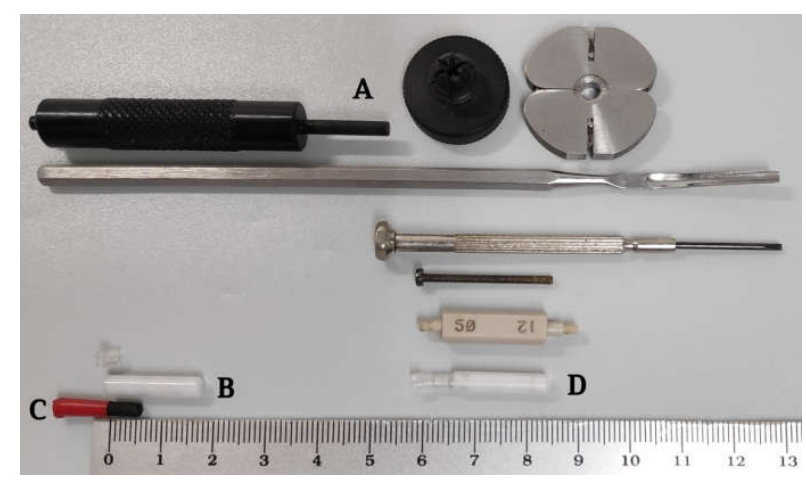

Figure 1. Materials used for sample packaging: (A) hand tools; (B) routine $4 \mathrm{~mm}$ r-rotor; (C) plastic cylinder for free volume control; and (D) special $50 \mu \mathrm{L}$ HRMAS $4 \mathrm{~mm}$ c-rotor

Acquisition of ${ }^{27} \mathrm{Al}$ solid-state NMR spectra $\left({ }^{27} \mathrm{Al}\right.$ MAS NMR): The ${ }^{27} \mathrm{Al}$ MAS NMR spectra were acquired on a Bruker instrument, model Avance III 400WB (9.4T) switched at a frequency of 104.23 $\mathrm{MHz}\left(v_{\text {Larmor }}\right.$ of $\left.{ }^{27} \mathrm{Al}\right)$, equipped with a Bruker CPMAS triple channel $4 \mathrm{~mm}$ probe. The samples were analysed at the same temperature, thus excluding error due to variation in the $\mathrm{Q}$ factor of the probe head (Haouas et al., 2018). Since all the samples were spun at a rotation speed of $12 \mathrm{kHz}$ and the bearing air was maintained at 293-294 K, the samples were analysed at $306 \mathrm{~K}$ (Grimmer et al., 1997), taking into account the effect of frictional heating during the rotation at this spinning rate. This spinning speed was sufficient to avoid the need of correction for sidebands in integral region data. The chemical shifts were referenced to the $\mathrm{AlCl}_{3} \cdot 6 \mathrm{H}_{2} \mathrm{O}$ signal and expressed in the ppm units defined in Equation 1: 
$p p m=\frac{v_{o b s}(\mathrm{~Hz})-v_{r e f}(\mathrm{~Hz})}{v_{\text {Larmor }}{ }^{27} \mathrm{Al}(\mathrm{MHz})} \cdot 10^{6}$

Where is the frequency observed for the signal, is the frequency of the reference sample $(0.0 \mathrm{~Hz})$ and is the Larmor frequency of ${ }^{27} \mathrm{Al}$, which depends on the magnetic field $B_{o}$. We used a single pulse sequence (Bloch decay) with an excitation pulse of $1.03 \mu \mathrm{s}(\pi / 12)$ and a $1 \mathrm{~s}$ recycle time (D1). This value was more than five times the longest longitudinal relaxation times (T1) for the $\mathrm{Al}$ sites, which were measured by inversion-recovery pulse sequence (Figure S1, Supplementary Material) as $0.0157 \mathrm{~s}\left(\mathrm{Al}^{\mathrm{IV}}\right)$ and $0.0195 \mathrm{~s}\left(\mathrm{Al}^{\mathrm{VI}}\right)$. The probe was re-tuned after each sample change. To ensure good spectral quality, the processing was performed with manual phase correction and automatic correction of the baseline, and integrations were performed manually. In solution-state NMR, it is advisable to use an integration range wider than at least $25 \mathrm{X}_{1 / 2}$ (Suiter et al., 2019). Unfortunately, our signals have widths on the order of $2 \mathrm{kHz}$, so this condition could not be fulfilled. The integration was performed in the range of $90 \mathrm{ppm}$ to $-80 \mathrm{ppm}$ to cover only the signal areas. The contributions of spinning sidebands (ssb) from the central transitions and from satellite excitations were addressed through a series of integrations, measured by considering or not the first-order ssb. The results (Table S2, Supplementary Material) showed that approximately $99 \%$ of the Al response area was covered when only the first-order signals of each type of $\mathrm{Al}$ were integrated, in accordance with Malz and Jancke (2005). Between 512 and 2048 scans (NS) were used in a $100 \mathrm{kHz}$ spectral window to maintain a signal/noise ratio $(\mathrm{S} / \mathrm{N})$ greater than 200 in all spectra. The signal/noise $(\mathrm{S} / \mathrm{N})$ ratio was measured electronically by using the TopSpin 3.2 Software, following Equation 2:

$\frac{\text { signal }}{\text { noise }}=\frac{N S}{\sqrt{N S}}, \quad$ where NS is the number of scans

Validation: In the selectivity/specificity assays, the blank of the reference substance and the diluent (NaCl, Sigma Aldrich P.A., 99\%) were analysed. The working range and linearity were determined according to the specifications (ABNT, 2016; ANVISA, 2003; EURACHEM/CITAC, 2012; EUROLAB, 1/2014; INMETRO, 2001). In the linearity test, seven different amounts of the reference sample were weighed together with a given amount of the diluent to cover a range between $5 \%$ and $100 \%$ by weight. The mixtures were ground in a mortar for 30 minutes. A curve was constructed using $\mathrm{Al}_{2} \mathrm{O}_{3}$ and $\mathrm{NaCl}$ (diluent) at seven concentrations $(5 \%, 15 \%, 25 \%, 35 \%, 50 \%$, $75 \%$, and $100 \%$ ). The linearity of the method was determined from the working range curve and calculated from the linear regression equation (Equation 3):

$\mathrm{y}=\mathrm{ax}+\mathrm{b}$

where:

$y=$ Absolute area (from Topspin 3.2 software)

$\mathrm{x}=$ Concentration

$\mathrm{a}=$ Slope of the calibration curve (sensitivity)

$\mathrm{b}=$ Intersection with the $\mathrm{y}$-axis

Repeatability assays were performed with seven samples of different concentrations on two consecutive days by different operators. The precision can be expressed as the relative standard deviation (RDS) or coefficient of variation $(\mathrm{CV} \%)$, and all parameters were calculated using spreadsheet methods (Teófilo et al., 2006). The maximum acceptable value, not exceeding $5 \%$, is defined according to the methodology used, the concentration of the analyte in the sample, the type of matrix and the purpose of the method (INMETRO, 2011). The analyses for these tests were performed in triplicate, with three different masses, in the same way as described for the linearity and working range tests.

\section{RESULTS AND DISCUSSION}

Initially, the MAS NMR ${ }^{27} \mathrm{Al}$ spectrum of the reference sample was obtained (Figure 2, left). Two signals were observed at $63.9 \mathrm{ppm}$ and
$7.5 \mathrm{ppm}$, corresponding to the $\mathrm{Al}^{\mathrm{IV}}$ and $\mathrm{Al}^{\mathrm{VI}}$ sites, respectively, which are characteristic of this material (Fitzgerald et al., 1994). Parallel to the acquisition of the blank, measurements were performed to estimate the number of scans and the recycle time to establish the ideal parameters for acquisition of NMR spectra with S/N >200 and determine the absolute area factor (Equation 4), which was calculated for each type of rotor evaluated (theroutine r-rotor and c-rotor, containing ceramics and Kel-F inserts)

Absolute area factor $=\frac{\text { absolute area }(\text { from Topspin software })}{N S x \text { sample mass } x 19.62}$

From the absolute area measured electronically and provided by the TopSpin 3.2 software, it was established for the NMR spectra that the quantification would be based on the average spin count (area) per mmol Al, the number of scans (defined by $\mathrm{S} / \mathrm{N}>200$ ) and the absolute area factor generated for each rotor per gram of material (Equation 4), where ' 19.62 ' is the amount (in mmol) of aluminiumin a $1 \mathrm{~g}$ sample with $100 \% \mathrm{Al}_{2} \mathrm{O}_{3}$ content. In this way, the reported results were normalized to $\mathrm{mmol} \mathrm{Al}$ per gram of sample. The absolute area factor was measured on different days by using a reference sample, as shown in Table S3 (Supplementary Material).

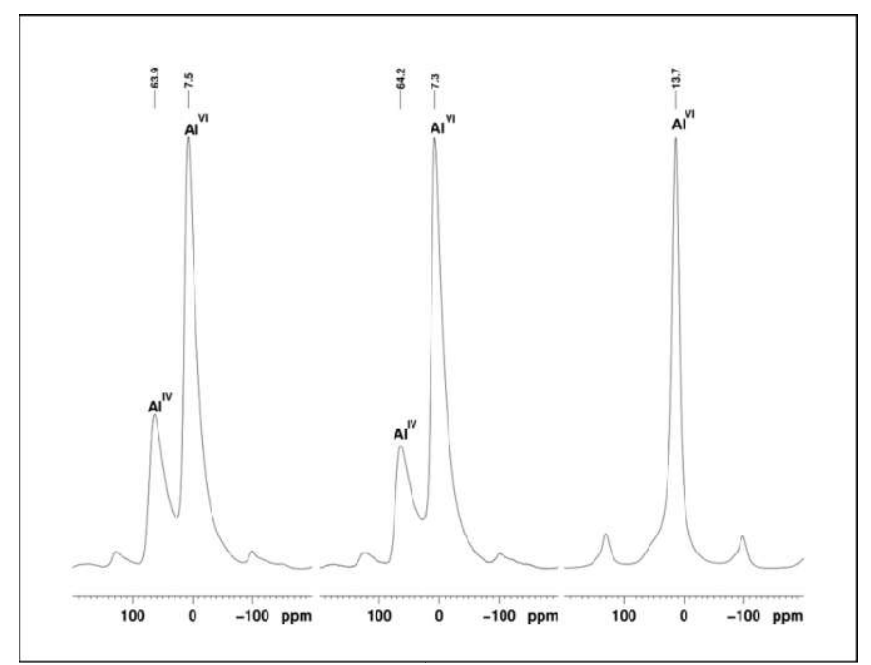

Figure $2 .{ }^{27} \mathrm{Al}$ MAS NMR spectra of the reference $\gamma$-alumina sample (left), $\gamma$-aluminaS (centre) and bauxite (right)

Analytical Method Validation: The method was validated according to distinct resolutions (ABNT, 2016; ANVISA, 2003; EURACHEM/CITAC, 2012; EUROLAB, 1/2014; INMETRO, 2001), whose purpose is to establish quantitative tests for raw materials. One of these resolutions, ANVISA advocates that the purpose of a validation is to demonstrate that the method is appropriate for the intended purpose, i.e., qualitative, semiquantitative or quantitative determination. The purpose of the specificity/selectivity assay is to ensure that the signals to be integrated for quantification correspond only to the analyte. For this purpose, the spectra of the reference substance and of the blank were separately obtained. It was evident from the extent of the signal areas in alumina that the signals present at $7.5 \mathrm{ppm}$ corresponds to octahedral sites and at $63.9 \mathrm{ppm}$ corresponds to tetrahedral aluminium sites, and that the analyte of interest do not exhibit interference from the diluent. The linearity curve was constructed with seven different concentrations of the analyte (Table S4, Supplementary Material), thus satisfying the recommendation of Resolution ANVISA RE No. 899 and EUROLAB. The interval was established by the smallest $(\approx 1 \mathrm{mmol}$ $\mathrm{Al})$ and highest $(19.6 \mathrm{mmol} \mathrm{Al})$ points of this curve, which resulted in a correlation coefficient $\left(\mathrm{R}^{2}\right)$ equal to 0.9939 (Figure 3 ).

As the value obtained was higher than the minimum acceptance criterion described in RE No. 899 ( $r \geq 0.99)$, the linearity test was considered valid. The nonzero y-intercept value, although intriguing, was already reported in the literature, as in the work of Bharti and Roy (2012), who found a linear coefficient during solution ${ }^{1} \mathrm{H}$ NMR quantitative determination. In our case, we believe that the observed 
linear coefficient could be due to the presence of trace amounts of $\mathrm{Al}$ in the coil region of the probe.

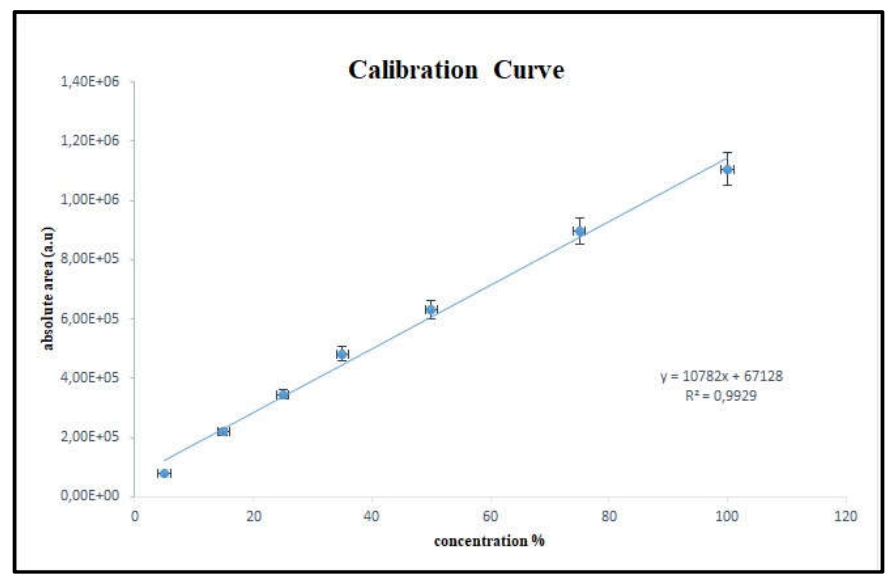

Figure 2. ${ }^{27} \mathrm{Al}$ MAS NMR spectra of the reference $\gamma$-alumina sample (left), $\gamma$-aluminaS (centre) and bauxite (right)

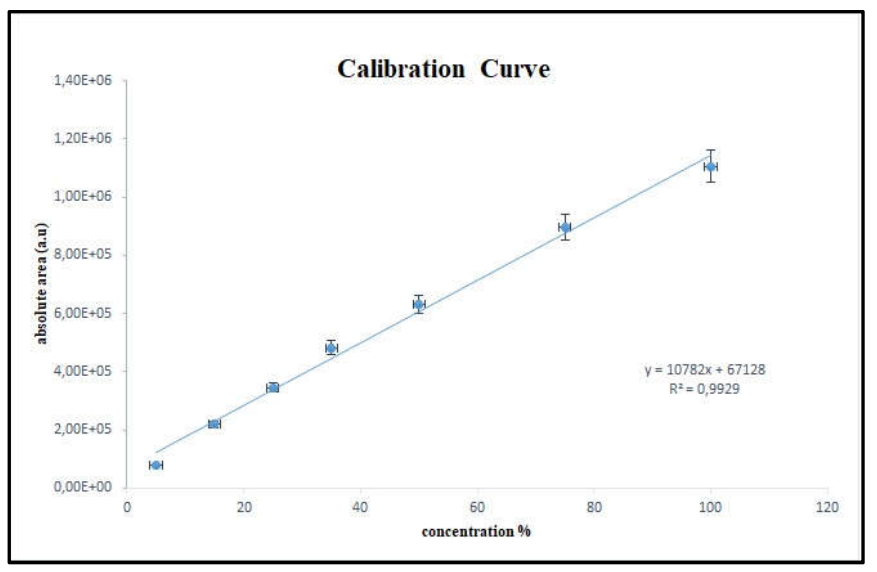

Figure 3. Linearity analytical curve for the quantification of Al by ${ }^{27}$ Al MAS NMR

It is noteworthy that although the standards require the linearity test, in the case of the use of NMR, the need for this assay may be questioned due to the particularities of this analytical tool. In spectroscopic techniques such as UV and IR, the signal areas depend on specific properties of the molecules, such as the molar absorbance (for UV and IR) and the dipole moment (for IR), in addition to the respective concentrations (Roggo et al., 2007). This phenomenon does not occur for the area of the NMR signals of the same sample, which depends only on the number of nuclei that absorb energy in the radiofrequency region, that is, the concentration.

Accuracy: The accuracy test was carried out by applying the proposed analytical method tothe analysis of a substance of known purity: the alumina reference sample. The mean experimental concentration values were calculated, and the accuracy was determined from Equation 5. The mean result found in the accuracy test was $97.8 \%$ - 98\%. Although some international references do not establish accuracy parameters, our results are in accordance with the range of values accepted for the test (98\% - 102\%) according to the ABNT (2016).

Accuracy $(\%)=\frac{\text { experimental mean concentration }}{\text { theoretical concentration }} .100$ (Eq.5)

Precision: The repeatability, reproducibility and intermediate accuracy tests evaluate the accuracy of ananalytical method, which can be expressed as the relative standard deviation (RDS\%) or coefficient of variation (CV\%). The precision in the working range is presented in the form of the repeatability and intermediate accuracy, and the relative standard deviation of the obtained results is evaluated
INMETRO (2011). The intermediate accuracy test was performed by a second analyst after two days, according to what is recommended in the regulations. In this work, the reproducibility test was not performed since it is not required for the granting of registration. The results obtained in both assays are presented in Table S5 (Supplementary Material) and were considered adequate, as they resulted in an RSD of less than $5.0 \%$, according to the international resolution ANVISA (2003). In the repeatability assay, a value of $0.6 \%$ was obtained, and in the intermediate accuracy assays, a value of $2.1 \%$ was obtained (analyst $\mathrm{A}=0.6 \%$ and analyst $\mathrm{B}=2.1 \%$ ). The knowledge of these values allows the uncertainty of the method to be estimated when necessary, thus guaranteeing better security in decision making.

Limits of Detection and Quantification: The limit of detection is the lowest concentration of analyte in a sample that is adequate for detection but not necessarily quantified. The limit of quantification is the lowest concentration of analyte in a sample that can be quantitatively determined with suitable precision and accuracy. The limits of detection and quantification (LOD and LOQ, respectively) are not applicable to major component methods but can be calculated based on the standard deviation of the response $\sigma$ and the slope $S$ of a calibration curve obtained in a linearity study (INMETRO,2011). The results for the limits of detection and quantification at the 95, 99 and 99.9\% confidence levels are, respectively 1.9, 2.7 and 3.6 mmol Al.g

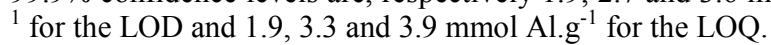

Robustness: The robustness test is important to verify the susceptibility of the method to variations in the analytical conditions. These variations should be controlled, and precautions should be taken in the procedure ANVISA (2003). The robustness of the method was estimated by independently varying three parameters: (i) the number of scans; (ii) the relaxation delay; and (iii) the pulse width. The results showed that this method was quite robust because they presented little variation with the parameters (Table S6, Supplementary Material). Table 2 shows the mean results obtained in the validation tests of the analytical method proposed in this work.

Table 2. Mean results of the validation parameters forqNMR

\begin{tabular}{lll}
\hline Test & Result & Accepted value $^{\mathrm{a}}$ \\
\hline Linearity & 0.9975 & $\mathrm{r} \geq 0.99$ \\
Accuracy & $\approx 98 \%$ & $98-102 \%$ \\
Repeatability & RSD 0.6\% & RSD $\leq 5.0 \%$ \\
Intermediate Accuracy & RSD 2.1\% & - \\
Robustness & RSD 2.6\% & - \\
\hline${ }^{a}$ ref [(EUROLAB, 1/2014; ANVISA, 2003; \\
\multicolumn{2}{l}{ INMETRO, 2001; EURACHEM/CITAC, 2012; ABNT, 2016)] }
\end{tabular}

Quantification: As an application of the developed protocol for quantification of $\mathrm{Al}$ in diamagnetic samples by ${ }^{27} \mathrm{Al}$ MAS NMR, some diamagnetic samples were analysed: a sample of certified bauxite, a $\gamma$-aluminaS sample synthesized in the laboratory, and a series of alumina and diamagnetic niobium and molybdenum metal supported alumina samples with distinct compositions to characterize and quantify the $\mathrm{Al}$ sites present. The ${ }^{27} \mathrm{Al}$ MAS NMR spectra of the $\gamma$-aluminaS and bauxite samples are shown in Figure 2 (centre and right, respectively). The synthetized $\gamma$-alumina displays a profile similar to that of the reference alumina, with maxima at $64.2 \mathrm{ppm}$ $\left(\mathrm{Al}^{\mathrm{IV}}\right)$ and $7.3 \mathrm{ppm}\left(\mathrm{Al}^{\mathrm{VI}}\right)$. The spectrum obtained for bauxite shows an $\mathrm{Al}^{\mathrm{VI}}$ signal with a maximum at $13.7 \mathrm{ppm}$ and a broad low intensity signal at approximately $60 \mathrm{ppm}\left(\mathrm{Al}^{\mathrm{IV}}\right)$. The $\mathrm{Al}$ levels obtained are listed in Table S7 (Supplementary Material). For the quantifications, the signals located in the range of $90 \mathrm{ppm}$ to $-80 \mathrm{ppm}$, corresponding to the central transition $(+1 / 2 \rightarrow-1 / 2)$ excitation, were integrated. The mean values of the results for the synthesized $\gamma$-alumina and bauxite samples obtained by counting the aluminium spins by NMR of solids using the routine rotor were in good agreement with those obtained by $\mathrm{XRF}$, considering an error percentage of up to $5 \%$ as acceptable for a semiquantitative analysis. 
Table 3. Results of the MAS NMR quantification of ${ }^{27} \mathrm{Al}$ inthe diamagnetic samples studied

\begin{tabular}{|c|c|c|c|c|c|c|c|}
\hline \multirow[t]{2}{*}{ Sample } & \multicolumn{2}{|c|}{ Al Content by XRF } & \multicolumn{3}{|c|}{ Al Content by NMR } & \multicolumn{2}{|c|}{$\mathrm{S} / \mathrm{N}$} \\
\hline & $\mathrm{Al}_{2} \mathrm{O}_{3}(\%)$ & $\mathrm{mmol} \mathrm{Al} \mathrm{g}^{-1}$ & $\begin{array}{c}\text { r-rotor } \\
\mathrm{mmol} \mathrm{Al} \mathrm{g}^{1}\end{array}$ & $(\%)^{\mathrm{c}}$ & $\begin{array}{l}\text { tor } \\
\mathrm{mmol} \mathrm{Al} \mathrm{g}\end{array}$ & $(\%)^{\mathrm{c}}$ & \\
\hline$\gamma$-aluminaS & $99.4^{\mathrm{a}}$ & 19.5 & $18.8 \pm 0.02$ & 96.3 & $19.3 \pm 0.02$ & 99.1 & 361.8 \\
\hline $\begin{array}{l}11 \mathrm{Nb}_{2} \mathrm{O}_{5} / \mathrm{Al}_{2} \mathrm{O}_{3} \\
20 \mathrm{Nb}_{2} \mathrm{O}_{5} / \mathrm{Al}_{2} \mathrm{O}_{3}\end{array}$ & $\begin{array}{l}88.9^{\mathrm{b}} \\
80.0^{\mathrm{b}}\end{array}$ & $\begin{array}{l}17.4 \\
15.7\end{array}$ & $\begin{array}{l}16.7 \pm 0.02 \\
15.0 \pm 0.02\end{array}$ & $\begin{array}{l}95.6 \\
95.5\end{array}$ & $\begin{array}{l}17.6 \pm 0.02 \\
15.4 \pm 0.01\end{array}$ & $\begin{array}{l}101.0 \\
98.4\end{array}$ & $\begin{array}{l}246.8 \\
235.6\end{array}$ \\
\hline $\begin{array}{l}\text { MoAl } \\
\text { MoNbAl }\end{array}$ & $\begin{array}{l}80.6^{\mathrm{b}} \\
65.9^{\mathrm{b}}\end{array}$ & $\begin{array}{l}15.8 \\
12.9\end{array}$ & $\begin{array}{l}15.0 \pm 0.03 \\
12.3 \pm 0.02\end{array}$ & $\begin{array}{l}95.1 \\
94.9\end{array}$ & $\begin{array}{l}15.4 \pm 0.01 \\
12.6 \pm 0.01\end{array}$ & $\begin{array}{l}97.1 \\
97.2\end{array}$ & $\begin{array}{l}246.1 \\
275.7\end{array}$ \\
\hline
\end{tabular}

a obtained by XRF (CETEM, RJ, Brazil).

${ }^{\mathrm{b}}$ nominal.

${ }^{c}$ relationship between the Al content detected by NMR and the theoretical or XRF analysis result.

It can be verified that the presence of iron at a concentration of $1.2 \%$ did not alter the results, in agreement with the report of Bakhmutov (2012), whose results showed that materials in which the concentration of paramagnetic centres are $\leq 0.5 \%-1 \%$ by weight can be considered as diamagnetic systems. Samples of $\mathrm{Nb}_{2} \mathrm{O}_{5} / \mathrm{Al}_{2} \mathrm{O}_{3}$ carriers containing $11 \%$ and $20 \% \mathrm{Nb}_{2} \mathrm{O}_{5}$ and Mo supported on $\mathrm{Al}_{2} \mathrm{O}_{3}$ and on the $\mathrm{Nb}_{2} \mathrm{O}_{5} / \mathrm{Al}_{2} \mathrm{O}_{3}$ support showed ${ }^{27} \mathrm{Al}$ MAS NMR spectra with the same profile (Figure 4), with the two signals typical of alumina, with distinction of the tetrahedral and octahedral aluminium coordination in the structure, and without any overlap of the signals, which makes the quantification possible. The spectra of the supports were integrated in the region of $90 \mathrm{ppm}$ to $-80 \mathrm{ppm}$ after processing, and calculations were performed based on the mass of each sample on the routine rotor and the special rotor, the number of scans and the integrated area. The values of the aluminium content in mmol Al per gram were compared with the results obtained by chemical analysis and are presented in Table 3.

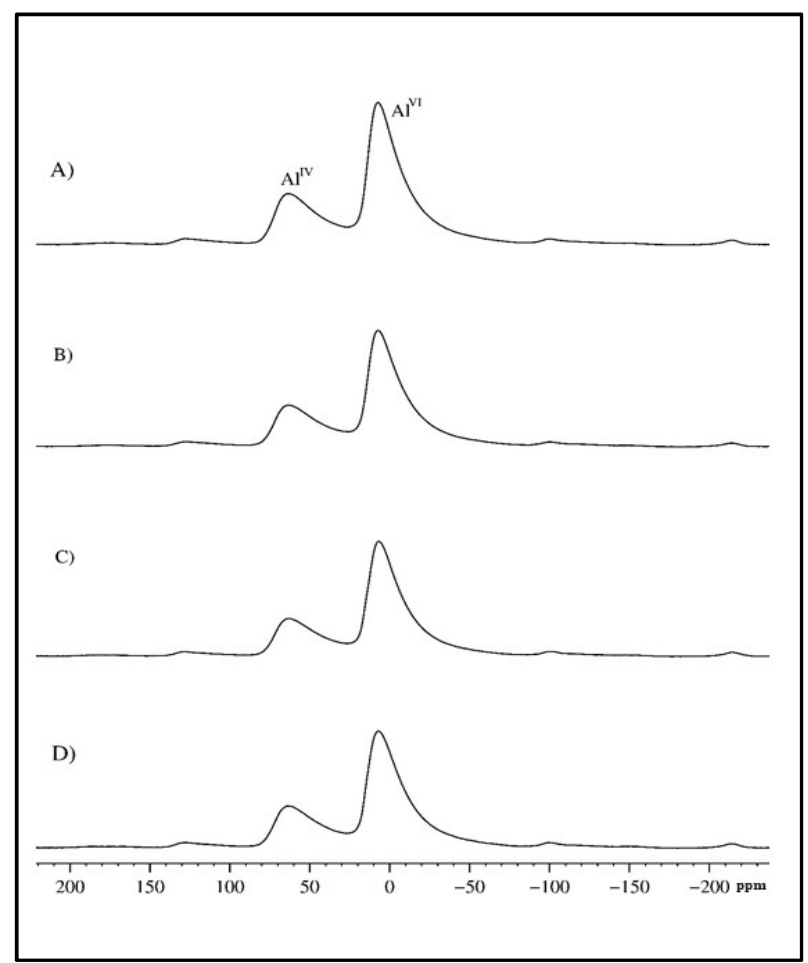

Figure $4 .{ }^{27} \mathrm{Al}$ MAS NMR spectra of supports and catalysts containing $\mathrm{Nb}$ and/or $\mathrm{Mo}$ : A) $\left.11 \mathrm{Nb}_{2} \mathrm{O}_{5} / \mathrm{Al}_{2} \mathrm{O}_{3}, \mathrm{~B}\right) 20 \mathrm{Nb}_{2} \mathrm{O}_{5} / \mathrm{Al}_{2} \mathrm{O}_{3}$, C) MoAl and D) MoNbAl.

The niobium-containing aluminas presented aluminium spin count values relative to the $\mathrm{Al}$ content obtained by XRF of $95.6 \%$ for $11 \mathrm{Nb}_{2} \mathrm{O}_{5} / \mathrm{Al}_{2} \mathrm{O}_{3}$ and $95.5 \%$ for $20 \mathrm{Nb}_{2} \mathrm{O}_{5} / \mathrm{Al}_{2} \mathrm{O}_{3}$ with the routine rotor and of $101.0 \%$ for $11 \mathrm{Nb}_{2} \mathrm{O}_{5} / \mathrm{Al}_{2} \mathrm{O}_{3}$ and $98.4 \%$ for $20 \mathrm{Nb}_{2} \mathrm{O}_{5} / \mathrm{Al}_{2} \mathrm{O}_{3}$ for the special rotor. It can be noted that the presence of niobium in the support did not hamper the quantification of aluminium. For the supported molybdenum catalysts, again in relation to the XRF results, 95.1\% was obtained for $\mathrm{MoAl}$ and $94.9 \%$ for MoNbAl with the rrotor, and $97.1 \%$ was obtained for $\mathrm{MoAl}$ and $97.2 \%$ for $\mathrm{MoNbAl}$ with the c-rotor. Thus, it can be seen that the impregnation of molybdenum in the alumina-containing supports does not disturb the quantification by counting of the Al spins. These results were similar to those reported by Ziarelli et al. (2007), in the quantification of drug samples using ${ }^{13} \mathrm{C}$ CP MAS NMR and Brinkmann et al. (2019), in ${ }^{19} \mathrm{~F}$ quantitative solid-state NMR, demonstrating that the quadrupolar nuclei in solid-state NMR can be used in the quantitative evaluation of detectable aluminium, similar to the quantitative analysis of dipolar nuclei in solids. It was observed that the quantification of aluminium in this series of diamagnetic samples using ${ }^{27} \mathrm{Al}$ MAS NMR was satisfactory for both types of rotors; considering a percentage error of up to $5 \%$ as being acceptable, both presented values $<5 \%$. The slightly worse results obtained for routine rotors could be due to the presence of a small volume of detected sample located in a lower region of the routine $4 \mathrm{~mm}$ rotors. In contrast, in the specially designed rotor used by Ziarelli et al. this region contains no sample due to the introduction of inserts, Kel-F inserts and Kel-F spacers, as seen in Ziarelli et al. (2007) report. This result is very important considering that in solid-state NMR laboratories, ordinary $4 \mathrm{~mm} \mathrm{ZrO}$ solid rotors are available for routine analysis. Our results showed that routine rotors can be used not only for qualitative experiments but also for quantitative determinations of the different types of quadrupolar $\mathrm{Al}$ sites present in diamagnetic samples. Application of this procedure to alumina-based materials containing paramagnetic sites is in progress and will be shown in a forthcoming publication.

\section{CONCLUSION}

It was possible to develop and validate an $\mathrm{Al}$ quantification protocol involving spin counting based on ${ }^{27} \mathrm{Al}$ MAS NMR spectra. The viability of using commercial and routine $4 \mathrm{~mm}$ rotors was demonstrated. The values obtained in the quantification of $\mathrm{Al}$ by ${ }^{27} \mathrm{Al}$ MAS NMR using $4 \mathrm{~mm} \mathrm{ZrO}_{2}$ rotors were considered excellent compared to those obtained with special $\mathrm{ZrO}_{2}$ rotors containing ceramics and Kel-F inserts, with satisfactory results being obtained with errors of up to $5 \%$. The sample has to be preferably located in the coil region so that the ${ }^{27} \mathrm{Al}$ solid $\mathrm{NMR}$ analysis response corresponds to the amount of $\mathrm{Al}$ present. This is achieved through compact packaging and "dead volume" control between the Kel-F cap and the sample. The obtained results showed that it is possible to apply the NMR method to quadrupolar nuclei in diamagnetic materials for the quantitative evaluation of detectable aluminium, similar to the method used for dipolar nuclei.

Acknowledgments: This work was supported by CETEM, PETROBRAS, ANP, PRH01, FAPERJ and CNPq. Luizianne P. Alves acknowledges CAPES and Leandro B. Borré acknowledges FINEP for scholarships.

\section{REFERENCES}

ABNT; NBR 14029 2016. Agrotóxicos e Afins-Validação de Métodos Analíticos.

Al-Fatesh AS, Fakeeha AH, Ibrahim AA, Khan WU, Atia H, Eckelt R, Seshan K, Chowdhury B. 2018. Decomposition of methane over alumina supported $\mathrm{Fe}$ and $\mathrm{Ni}-\mathrm{Fe}$ bimetallic catalyst: Effect 
of preparation procedure and calcination temperature J. Saudi Chem. Soc. 22:239-247

Ananthanarayanan A, Kothiyal GP, Montagne L, Revel, B. 2010. MAS-NMR studies of lithium aluminum silicate LAS glasses and glass-ceramics having different Li2O/Al2O3 ratio, J. Solid State Chem 183:120-127.

ANVISA 2003. Resolução-RE nº 899, de 29 demaio de 2003. Brasil, Ministério da Saúde.

Arias S, Eon JG, San Gil RAS, Licea YE, Palacio LA, Faro Jr., A 2013. Synthesis and characterization of terephthalateintercalated $\mathrm{NiAl}$ layered double hydroxides with high $\mathrm{Al}$ content, Dalton Trans. 42:2084.

Bakhmutov VI 2012. Solid State NMR in Materials Science. Chichester, U.K.: Wiley, pp. 191. Benndorf C, Eckert H, Janka O 2017. Structural Characterization of Intermetallic Compounds by 27Al Solid State NMR Spectroscopy, Acc. Chem. Res. 50:1459-1467.

Bharti SK, Roy R 2012. Quantitative ${ }^{1} \mathrm{H}$ NMR spectroscopy. TrAC Trends in Analytical Chemistry. 35:5-26.

Brinkmann A, Raza M, Melanson JE 2019. Metrologically traceable quantification of trifluoroacetic acid content in peptide reference materials by ${ }^{19} \mathrm{~F}$ solid-state NMR Metrologia 56:024002

Chagas LH, De Carvalho GSG, San Gil RAS, Chiaro SSX, Leitão AA, Diniz R 2014. Obtaining aluminas from the thermal decomposition of their different precursors: $\mathrm{An}{ }^{27} \mathrm{Al}$ MAS NMR and X-ray powder diffraction studies, Mater. Res. Bull. 49:216222.

Claude V, Mahy JG, Wolfs C, Lambert SD 2020. Physico-chemical properties of alumina supports modified with silicon alkoxides, J. Solid State Chem. 282:121102.

Constantino VRL, Araki K, Silva DO, Oliveira W 2002. Preparação de compostos de alumínio a partir da bauxita: considerações sobre alguns aspectos envolvidos em um experimento didático, Quím. Nova 25:490-498.

Crosson GS, Choi S, Chorover J, Amistadi MK, O'Day PA, Mueller KT 2006. Solid-State NMR Identification and Quantification of Newly Formed Aluminosilicate Phases in Weathered Kaolinite Systems. Phys. Chem. B. 110:723-732.

EURACHEM/CITAC guide 2012: Quantifying Uncertainty in Analytical Measurement, 3rd ed., London.

EUROLAB Technical Report 1/2014, 2014. Guide to NMR Method Development and Validation - Part I: Identification and Quantification. EUROLAB.

Firdous N, Janjua NK 2019. CoPtx $/ \gamma-\mathrm{Al}_{2} \mathrm{O}_{3}$ bimetallic nanoalloys as promising catalysts for hydrazine electrooxidation, Heliyon. 5:e01380.

Fitzgerald JJ, Kohl SD, Piedra G, Dec SF, Maciel GE, 1994. Observation of Four-Coordinate Aluminum Oxynitride $\mathrm{AlO}_{4-}{ }^{-} \mathrm{N}_{\mathrm{x}}$ Environments in AlON Solids by MAS ${ }^{27} \mathrm{Al}$ NMR at $14 \mathrm{~T}$, Chem Mater. 6:1915-1917.

Fyfe CA, Bretherton JL, Lam LY. 2001. Solid-State NMR Detection, Characterization, and Quantification of the Multiple Aluminum Environments in US-Y Catalysts by 27AlMAS and MQMAS Experiments at Very High Field. J. Am. Chem. Soc. 123:52855291.

Gee M, Wasylishen RE. 2001. Hyperfine Parameters for Aluminum Hydride: An ab Initio Molecular Orbital Study, J. Mol. Spectrosc. 207:153-160.

Grimmer AR, Kretschmer A, Cajipe VB. 1997. Influence of Magic Angle Spinning on SampleTemperature, Magn.Reson.Chem. 35:86-90.

Haouas M 2018. Nuclear Magnetic Resonance Spectroscopy for In Situ Monitoring of Porous Materials Formation under Hydrothermal Conditions, Materials 11:1416.

Haouas M, Taulelle F, Martineau C 2016. Recent advances in application of 27Al NMR spectroscopy to materials science, Prog Nucl Magn Reson Spectrosc. 94-95:11-36.

INMETRO; CGCRE-008 2011. Orientação sobre Validação de Métodos Analíticos.

Jiao J, Kanellopoulos J, Wang W, Ray SS, Foerster H, Freudeb D, Hunger M. 2005. Characterization of framework and extraframework aluminum species in non-hydrated zeolites $\mathrm{Y}$ by
27Al spin-echo, high-speed MAS, and MQMAS NMR spectroscopy at $\mathrm{B}_{0}=9.4$ to $17.6 \mathrm{~T}$, Phys. Chem. Chem. Phys. 7:3221-3226.

Li M, Li H, Jiang F, Chu Y, Nie H 2009. Effect of surface characteristics of different alumina on metal-support interaction and hydrodesulfurization activity, Fuel 88:1281-1285.

Lima SH, Forrester AMS, Palacio LA, Faro Jr A 2014. Niobiaalumina as methanol dehydration component in mixed catalyst systems for dimethyl ether production from syngas, Appl. Catal. A 488:19-27.

Liu CC, Maciel GE. 1996. Quantitative Analysis of Solids by HighResolution 1H NMR Anal. Chem. 68:1401-1407.

Liu D, Dai F, Tang Z, Liu Y, Liu C. 2015. The structure-directed effect of Al-based metal-organic frameworks on fabrication of alumina by thermal treatment, Mater. Res. Bull. 65:287-292.

Liu XM, Xue HX, Li XL, Yan ZF. 2010. Synthesis and hydrodesulfurization performance of hierarchical mesopores alumina, Catal. Today 158:446-451.

Malz F, Jancke H 2005. Validation of quantitative NMR. J. Pharm. Biomed. 38:813-823.

Man PP, Klinowski J 1988. Quantitative Determination of Aluminium in Zeolites by Solid-state 27Al NMR Spectroscopy J. Chem. Soc., Chem. Commun. 1291-1294.

Mingyue L, Wei X, Yongchao S. 2021. Solid-state NMR spectroscopy in pharmaceutical sciences. TrAC Trends in Analytical Chemistry. 135:116152

Paglia G, Buckley CE, Rohl A, Hunter BA, Har RD, Hanna JV, Byrne LT 2003. Tetragonal structure model for boehmitederived $\gamma$-alumina, Phys. Rev. B 68:144110.

Rocha A, Faro A, Oliviero L, Van Gestel J, Maugé F 2007. Alumina-, niobia-, and niobia/alumina-supported NiMoS catalysts: Surface properties and activities in the hydrodesulfurization of thiophene and hydrodenitrogenation of 2,6-dimethylaniline, J. Catal. 252:321-334.

Roggo Y, Chalus P, Maurer L, Lema-Martinez C, Edmond A, Jent N 2007. A review of near infrared spectroscopy and chemometrics in pharmaceutical technologies, J. Pharm. Biomed. Anal. 44:683-700.

Saini A, Jat SK, Shekhawat DS, Kumar A, Dhayal V, Agarwal DC 2017. Oxime-modified aluminium III alkoxides: Potential precursors for $\gamma$-alumina nano-powders and optically transparent alumina film, Mater. Res. Bull. 93:373-380.

Sanchez S, Ziarelli F, Viel S, Delaurent C, Caldarelli S 2008. Improved solid-state NMR quantifications of active principles in pharmaceutical formulations J. Pharm. Biomed. Anal. 47:683-7

Smernik RJ, Oades JM. 2000. The use of spin counting for determining quantitation in solid state ${ }^{13} \mathrm{C}$ NMR spectra of natural organic matter. 1. Model systems and the effects of paramagnetic impurities, Geoderma 96:101-129.

Smith ME, Van Eck ERH 1999. Recent advances in experimental solid state NMR methodology for half-integer spin quadrupolar nuclei Progress in Nuclear Magnetic Resonance Spectroscopy 34:159-201.

Suiter CL, McLinden MO, Bruno TJ, Widegren JA. 2019. Composition Detemination of Low-Pressure Gas-Phase Mixtures by ${ }^{1} \mathrm{H}$ NMR Spectroscopy Anal. Chem. 91:4429-35

Teófilo RF, Ferreira MMC 2006. Quimiometria II: planilhas eletrônicas para cálculos de planejamentos experimentais, um tutorial, Quím. Nova 29:338-350.

Wang Z, Opembe N, Kobayashi T, Nelson NC, Slowing II, Pruski M 2018. Quantitative atomic-scale structure characterization of ordered mesoporous carbon materials by solid state NMR, Carbon 131:102-110.

Wawer I. 2008. qNMR in Solid State, in: I. Wawer, B. Diehl, U. Holzgrabe Eds.. NMR Spectroscopy in Pharmaceutical Analysis, Elsevier Science: Amsterdam. pp. 63-82.

Weissman JG. 1996. Niobia-alumina supported hydroprocessing catalysts: relationship between activity and support surface acidity Catal. Today 28:159-166.

Ziarelli F, Viel S, Sanchez S, Cross, Caldarelli S 2007. Precision and sensitivity optimization of quantitative measurements in solid state NMR, J. Magn. Reson. 188:260-266. 
Table S4. Results of the Repeatability and Intermediate Accuracy tests

\begin{tabular}{|c|c|c|c|c|c|c|c|}
\hline & & \multicolumn{3}{|l|}{ Repeatability } & \multicolumn{3}{|c|}{ IntermediateAccuracy } \\
\hline $\begin{array}{l}\text { Sample } \\
(\% \mathrm{p} / \mathrm{p})\end{array}$ & replicate & Area byNS & $\begin{array}{l}\text { NMR AlContent } \\
\text { exp. (\%) AnalystA }\end{array}$ & $\begin{array}{l}\text { NMR AlContent exp } \\
.(\%) \text { AnalystB }\end{array}$ & Area byNS & $\begin{array}{l}\text { NMR Al Content exp. (\%) } \\
\text { AnalystA }\end{array}$ & $\begin{array}{l}\text { NMR AlContent } \\
\text { exp. }(\%) \text { AnalystB }\end{array}$ \\
\hline 25 & rep1 & 358884.2 & 4.7 & 98.1 & 345000.8 & 4.6 & 93.1 \\
\hline 25 & rep2 & 359819.4 & 4.8 & 98.1 & 342805.7 & 4.5 & 92.5 \\
\hline 25 & rep3 & 363686.4 & 4.8 & 98.0 & 344299.2 & 4.6 & 92.9 \\
\hline & & & & & & & \\
\hline 50 & rep1 & 634370.7 & 9.5 & 97.1 & 638358.2 & 9.5 & 97.3 \\
\hline 50 & rep2 & 635627.0 & 9.5 & 97.0 & 619882.1 & 9.3 & 94.6 \\
\hline 50 & rep3 & 636428.9 & 9.5 & 97.1 & 642682.4 & 9.6 & 98.1 \\
\hline 100 & rep1 & 1109871.6 & 19.1 & 98.5 & 1066645.6 & 18.3 & 93.5 \\
\hline 100 & rep2 & 1106209.5 & 19.0 & 98.2 & 1073948.1 & 18.5 & 94.1 \\
\hline \multirow[t]{4}{*}{100} & rep3 & 1104215.2 & 19.0 & 97.2 & 1078222.4 & 18.5 & 94.5 \\
\hline & & & Average & 97.8 & & Average & 94.5 \\
\hline & & & SD & 0.6 & & SD & 2.0 \\
\hline & & & RSD(\%) & 0.6 & & RSD (\%) & 2.1 \\
\hline
\end{tabular}

Table S5. Results of robustness tests

\begin{tabular}{|l|l|l|l|}
\hline \multirow{5}{*}{ Parameter } & Change & $\begin{array}{l}\text { Recorvered } \\
(\mathrm{mmol} \mathrm{Al} \mathrm{g})^{\mathrm{a}}\end{array}$ & mass \\
\hline \multirow{5}{*}{ Relaxa) }
\end{tabular}

Table S6 - Results of ${ }^{27}$ Al NMR-MAS quantification of samples of synthesized $\gamma$-aluminaS and certified Bauxite. ${ }^{\mathrm{a}}$

\begin{tabular}{|c|c|c|c|c|c|c|c|c|c|}
\hline \multirow[t]{2}{*}{ Sample } & \multicolumn{2}{|c|}{ Content $\mathrm{Al}^{\mathrm{b}}$} & \multirow[t]{2}{*}{ Signal Area by NS } & \multicolumn{2}{|c|}{ Content $\mathrm{Al}$ by NMR } & \multicolumn{2}{|l|}{ Average } & \multirow[t]{2}{*}{$\mathrm{SD}^{\mathrm{c}}$} & \multirow[t]{2}{*}{$\mathrm{RSD}^{\mathrm{d}}$} \\
\hline & $\% \mathrm{Al}_{2} \mathrm{O}_{3}$ & mmol $\mathrm{Al} \mathrm{g}^{-1}$ & & $\mathrm{mmol} \mathrm{Al} \mathrm{g}^{-1}$ & $\%{ }^{\mathrm{e}}$ & $\mathrm{mmol} \mathrm{Al} \mathrm{g}^{-1}$ & $\%^{\mathrm{e}}$ & & \\
\hline & & & 1240229.1 & 18.7 & 95.9 & & & & \\
\hline \multirow[t]{4}{*}{$\gamma$-aluminaS } & 99.4 & 19.5 & 1246440.6 & 18.8 & 96.4 & 18.8 & 96.2 & 0.2 & 0.3 \\
\hline & & & 1245385.4 & 18.8 & 96.3 & & & & \\
\hline & & & & & & & & & \\
\hline & & & 2170538.1 & 16.2 & 97.4 & & & & \\
\hline \multirow[t]{2}{*}{ Bauxite } & 85.0 & 16.7 & 2157984.8 & 16.1 & 96.9 & 16.2 & 96.8 & 0.6 & 0.7 \\
\hline & & & 2160254.0 & 16.2 & 96.9 & & & & \\
\hline
\end{tabular}

${ }^{\mathrm{a}} \mathrm{r}$-rotor ${ }^{\mathrm{b}}$ XRF. ${ }^{\mathrm{c}} \mathrm{SD}-\mathrm{Standard}$ Deviation. ${ }^{\mathrm{d}}$ RSD - Relative Standard Deviation. ${ }^{\mathrm{e}}$ relationship between the Al content detected by NMR by XRF analysis.

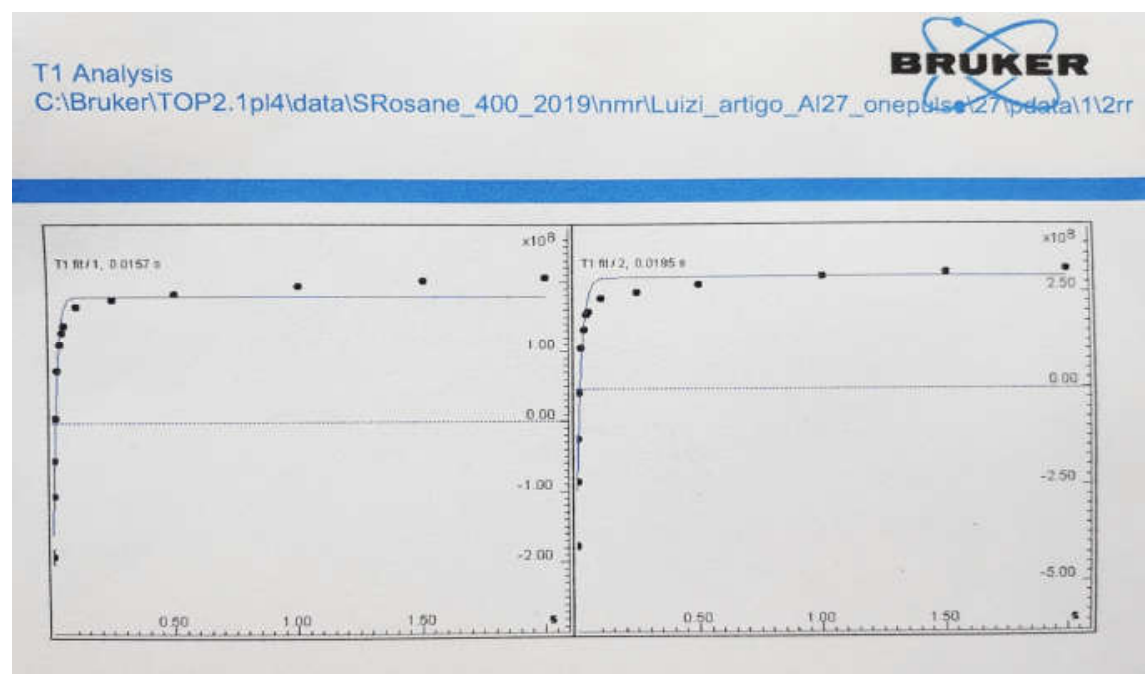

Figure S1-Measurement of $\mathrm{T}_{1} \mathrm{of}{ }^{27} \mathrm{Al}$ sites present in a reference sample of alumina by inversion-recovery pulse sequence. 